\title{
FREEDOM OF EXPRESSION AND ITS RESTRICTIONS IN EUROPE - ON THE APPLICABILITY OF ARTICLE 17 OF THE EUROPEAN CONVENTION OF HUMAN RIGHTS TO DISINFORMATION (FAKE NEWS)
}

\section{Davor DERENČINOVIĆ ${ }^{1}$}

Freedom of expression is not an absolute right and has limitations set up by international human rights treaties. The general clause of its limitation falls within the scope of the 'rights of others' as provided, for instance, in the European Convention of Human Rights. The role of the courts is to balance freedom of expression and the rights of others, performing a three-step test of legality, necessity, and proportionality of any restriction. However, according to the well-established case law of the European Court of Human Rights, some forms of expression do not enjoy protection under free speech clauses. Therefore, the European Court of Human Rights dismisses claims as manifestly inadmissible under Article 17. This 'abuse' clause is invoked when a particular claim is based on undermining the democratic values of a liberal state. The purpose of the abuse clause is to preserve the self-sustainability of the Convention. This paper aims to analyze whether fake news and disinformation campaigns fall under the scope of Article 17.

\begin{tabular}{|c|c|}
\hline & $\begin{array}{l}\text { freedom of expression } \\
\text { proportionality test } \\
\text { fake news } \\
\text { disinformation } \\
\text { free speech clause } \\
\text { exclusion clause } \\
\text { abuse clause }\end{array}$ \\
\hline
\end{tabular}

\section{Introduction}

Freedom of expression is one of the most fundamental values of a democratic and liberal state governed by the rule of law. ${ }^{2}$ Various international legal documents, both

1 | Professor, Faculty of Law, University of Zagreb, Croatia, davor.derencinovic@pravo.hr.

2 | According to the European Court of Human Rights 'freedom of expression constitutes one of the essential foundations of [democratic] society, one of the basic conditions for its progress and for the development of every man,' Handyside v. the United Kingdom, §49.

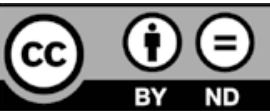


legally binding and non-binding, guarantee the freedom of expression and the right to manifest beliefs and opinions. This is a condicio sine qua non for exercising democratic plurality as a cornerstone of modern societies. The Convention on the Protection of Human Rights and Fundamental Freedoms (hereinafter Convention) ${ }^{3}$ in Art. 10 ensures that 'everyone has the right to freedom of expression...this right shall include freedom to hold opinions and to receive and impart information and ideas without interference by public authority and regardless of frontiers.' ${ }^{\prime 4}$ The European Court of Human Rights (Court) further developed a substance and the scope of this right. ${ }^{5}$ This article applies not only to 'information' or 'ideas' that are favorably received or regarded as inoffensive or as a matter of indifference but also to those that offend, shock, or disturb. ${ }^{6}$

The freedom of expression is not an absolute right. This could be restricted to certain conditions. The exclusion clause of Art. 10 stipulates that the exercise of free speech carries duties and responsibilities and therefore may be subject to such formalities, conditions, restrictions, or penalties as prescribed by law and are necessary in a democratic society. ${ }^{7}$ Other values whose protection could be used as grounds for restricting free speech are interests of national security, territorial disorder or crime, health or morals, reputation or rights of others, confidential information and authority, and impartiality of the judiciary. Following the text of the exclusion clause, the Court established through its rich case law that any restriction on the freedom of expression must be prescribed by law, must be necessary for a democratic society, and proportionate to the nature of the restriction. $^{8}$

However, there are certain forms of expression that are not protected under Art. 10 of the Convention. Using Art. 17 of the Convention, the Court can prima facie exclude some forms of expression from the protective reach of Art. 10. Art. 17 of the Convention, by some commentators described as a 'guillotine' provision ${ }^{9}$, serves the purpose of preventing applicants from claiming that the same Convention protects their speech that undermines the very foundations of the Convention. ${ }^{10}$ In cases where the Court establishes

3| The Convention for the Protecion of Human Rights and Fundamental Freedoms, better known as the European Convention on Human Rights, was opened for signature in Rome on November 4, 1950 and came into force on September 3,1953. It was the first instrument to give effect to certain of the rights stated in the Universal Declaration of Human Rights and make them binding. Available at https://www.echr.coe.int/pages/home.aspx?p=basictexts, Accessed August 27, 2021.

4 | Ibid. Art. 10., Accessed August 27, 2021.

5 | For comprehensive overview see Guide on Article 10 of the European Convention on Human Rights, European Court of Human Rights, December 2020, available at https://www.echr.coe.int/ documents/guide_art_10_eng.pdf, Accessed August 27, 2021.

6 | Observer and Guardian v. the United Kingdom, §59. For different understanding and legal evaluation of free speech see the US Supreme Court judgement in Brandenburg v. Ohio: '...the constitutional guarantees of free speech and free press do not permit a State to forbid or proscribe advocacy of the use of force or of law violation except where such advocacy is directed to inciting or producing imminent lawless action and is likely to incite or produce such action' Brandenburg v Ohio, at. 447-448.

7 | Supra note 2, article 10, §2, Accessed August 27, 2021.

8 | In literature it is also known as a 'three tests' concept: the first is the test of the lawfulness of the interference, the second is legitimacy of the aim pursued by the interference test and the third is necessity of the interference in a democratic society test. Supra note 4, p. 20. See also Observer and Guardian v. the United Kingdom; Prager and Oberschlick v. Austria.

9 | Tulkens, 2012.

10 | Ibid. 
grounds for applying Art. 17, the three-step test enshrined in Art. 10 would not apply. This short-track mechanism for rejecting claims of alleged free speech violations has been used to exclude hate speech from the protective function of Art. 10 of the Convention. In the Court's jurisprudence, it has been determined that, for instance, hate speech has not been protected under the free speech clause of Art. $10 .{ }^{11}$ Moreover, this kind of negative speech runs contrary to the text and spirit of the Convention and undermines the most fundamental values protected therein. ${ }^{12}$ Expressions excluded from the protective function of Art. 10 are also those related to the revision of well-established historical facts concerning Holocaust ${ }^{13}$, collective labeling, and negative stereotyping of certain ethnic and religious groups. Through its rich case law, the Court established that the free speech clause could not be used to protect expressions that are racist, anti-Semitic, or Islamophobic. ${ }^{14}$ In this regard, the Court 'has consistently held that sweeping statements attacking or casting in a negative light entire ethnic, religious, or other groups deserve no or very limited protection under Art. 10 of the Convention, read in the light of Art. 17.' ${ }^{15}$ The same position was taken with respect to the statements portraying non-European immigrant communities as criminally minded. ${ }^{16}$

The fake news phenomenon has been described in the literature as 'spreading outrageous distorted information to discredit opposition or create divisiveness between

11 | Guide on Article 17 of the European Convention on Human Rights, European Court of Human Rights, August 2020.

12 | See Gündüz v. Turkey, §41. The applicant in this case was a member of the religious Islamic sect who in directly broadcasted TV show openly advocated Sharia law and criticizing the concept of democracy. He was convicted by domestic courts for incitement to hatred and violence, but the Strasbourg Court found violation of article 10 because the impugned statements could not have been qualified as it was done by the authorities, nor they represented call to religious intolerance. Available at https://globalfreedomofexpression.columbia.edu/cases/gunduz-v-turkey/, Accessed 27 August 2021.

13 | Garaudy v. France, see infra under 2. This was the case about the applicant, author of the book 'The Founding Myths of Modern Israel' in which he disputed the crimes committed during the Holocaust. After being sued and fined under the Freedom of the Press Act in 1998 before domestic courts, he turned to the Court claiming his rights under article 10 have been violated because, according to him, the relevant passages in the book were dealing with Israeli politics rather than exposing antiSemitism and Holocaust denial. The Court found that the applicant advocated revisionist theories. According to the Court, '....there could be no doubt that disputing the existence of clearly established historical events, such as the Holocaust, did not constitute historical research akin to a quest for the truth. The real purpose of such a work was to rehabilitate the National-Socialist regime and, as a consequence, to accuse the victims of the Holocaust of falsifying history.' The article 17 was applied declaring the application inadmissible. Garaudy v. France, Inadmissibility decision, Press release issued by the Registrar, 2003.

14 | In Norwood v. the UK, the Court in its decision delivered in 2004 found that Islamophobic and anti-Muslim statements (Islam out of Britain-Protect British People) do not enjoy protection under article 10 . The case concerned a member of radical political party who put a poster on his apartment window with message that all Muslims must be removed from the country. The Court found that implying in general Muslims as terrorists run contrary to the very foundations of the Convention and gives rise to the application of Art. 17.

15 | Perinçek v. Switzerland, Grand Chamber, §206.

16 | Feret $v$. Belgium, Press release issued by the Registrar, 2009. Reiterating the importance of combating racial discrimination, the Court in Budinova and Chaprazov v. Bulgaria delivered in 2021 repeated that 'the fact that the author of the statements is a politician or speaks in his or her capacity as a member of parliament does not alter that.' Budinova and Chaprazov v. Bulgaria, § 94. 
opposing groups. ${ }^{17}$ According to another definition, fake news is 'false, often sensational, information disseminated under the guise of news reporting. ${ }^{18}$ The European Union defines disinformation as 'verifiable false or misleading information that is created, presented, and disseminated for economic gain or to intentionally deceive the public, and may cause public

harm.'19 For some commentators, the term is defined through its consequences as the destabilization of the category of truth in a democracy for geopolitical gain. ${ }^{20}$ According to some consequentialists, the fake news phenomenon creates an environment where 'emotion triumphs over reason, computational propaganda over common sense, or sheer power over knowledge. ${ }^{21}$ The phenomenon or concept of fake news (disinformation) was elaborated in my earlier paper on this topic written under this project (Social media, the freedom of expression and legal regulation of fake news in Croatia - not yet published at the moment of sending this paper for publication). Instead of being repetitive, I refer to the discussion on this issue. What is important, though, in the context of this paper, is the Council of Europe's position on this phenomenon in terms of its conceptual and substantive features. The first (and only) time when the Court applied the term 'fake news' was in the case of Brzeziński v. Poland in 2019. ${ }^{22}$ The case concerned a Polish candidate in the local elections. He harshly criticized local executives in his electoral booklet. This was referred to the domestic court that in a very short time (24 hours), according to special electoral legislation, found a violation of disseminating false information in the context of elections and banned its further distribution. Mr. Brzeziński turned to the Court in Strasbourg, claiming that his rights under Art. 10 were violated. The Court unanimously decided (under the simplified procedure provided in Art. 28 of the Convention) that the applicant's rights of free speech were violated by the authorities. This case was very interesting because, inter alia, the Court, for the first time, used the term 'fake news' in the decision ${ }^{23}$, even though neither the applicant nor the government did not mention it in their submissions. The Court was criticized for using this term, which was earlier found as inadequate and misleading. ${ }^{24}$ The group of experts appointed by the European Union also took a negative stance on this term. ${ }^{25}$

17 | Nielsen, 2020 cited by Dalkir and Katz, 2020, pp. 238-257.

18 | https://www.collinsdictionary.com/dictionary/english/fake-news, Accessed August 27, 2021.

19 | Communication from the Commission to the European Parliament, the Council, the European economic and social committee and the Committee of the regions tackling online disinformation: a European approach. com/2018/236 final. https:/eur-lex.europa.eu/legal-content/en/ txt/?uri=celex\%3a52018dc0236, Accessed August 27, 2021.

20 | Mueller, 2019.

21 | Peters et al. (eds.), 2018.

22 | See Fathaigh, 2019.

23 | Shattock, 2021.

24 | 'In this report, we refrain from using the term "fake news," for two reasons. First, it is woefully inadequate to describe the complex phenomena of information pollution. The term has also begun to be appropriated by politicians around the world to describe news organizations whose coverage they find disagreeable. In this way, it's becoming a mechanism by which the powerful can clamp down upon, restrict, undermine and circumvent the free press.' Information Disorder: Toward an interdisciplinary framework for research and policy making, Council of Europe, 2017, p. 5.

25 | In this report, the HLEG deliberately avoid the term 'fake news.' The HLEG do this for two reasons. Firstly, the term is inadequate to capture the complex problem of disinformation, which involves content that is not actually or completely 'fake' but fabricated information blended with facts, and practices that go well beyond anything resembling 'news' to include some forms of 
Further, in the text follows an attempt to analyze how to treat, in the context of Art. 17, fake news (disinformation) as a phenomenon that is often at the intersection with hate speech, revisionism of mass crimes, negative stereotyping of minorities, and other forms of speech that are prima facie excluded from the protective function of Art. 10 Convention. ${ }^{26}$

\section{Article 17 of the Convention}

Art. 17 of the Convention is a provision on prohibition of the abuse of rights. It reads as follows:

"Nothing in the Convention may be interpreted as implying for any State, group or person any right to engage in any activity or perform any act aimed at the destruction of any of the rights and freedoms set forth herein or at their limitation to a greater extent than is provided for in the Convention." 27

This provision is also known as the 'abuse' clause. In the context of Art. 17 as well as Art. $35 \S 3$ (a) the abuse means the 'harmful exercise of a right by its holder in a manner that is manifestly inconsistent with or contrary to the purpose for which such right is granted/designed. ${ }^{28}$ This provision, which was taken from the Universal Declaration of Human Rights (Art. 30), ${ }^{29}$ aims to protect the foundations of democratic society from antiliberal and totalitarian ideologies. The reasons for adhering to this protective clause are obvious. In adopting the text of the Convention, European governments were determined to prevent 'darkest pages of European history...by providing means that could rewrite them. ${ }^{\prime 30}$ In other words, the founding fathers of the Convention could not let room for the

automated accounts used for astroturfing, networks of fake followers, fabricated or manipulated videos, targeted advertising, organized trolling, visual memes, and much more. It can also involve a whole array of digital behavior that is more about circulation of disinformation than about production of disinformation, spanning from posting, commenting, sharing, tweeting and re-tweeting etc. Secondly, the term 'fake news' is not only inadequate, but also misleading, because it has been appropriated by some politicians and their supporters, who use the term to dismiss coverage that they find disagreeable, and has thus become a weapon with which powerful actors can interfere in circulation of information and attack and undermine independent news media. Research has shown that citizens often associate the term 'fake news' with partisan political debate and poor journalism broadly, rather than more pernicious and precisely defined forms of disinformation.' A multi-dimensional approach to disinformation, Report of the independent High level group on fake news and online disinformation, European Union, 2018, p. 10.

26 | Supra note 22

27 | Supra note 2.

$28 \mid$ Mirolubovs and Others v. Latvia, §§ 62 and 65; S.A.S. v. France, Grand Chamber, § 66. In supra note 10: 'In order to establish whether a particular conduct amounts to an abuse of rights, the Court scrutinises the aims which an applicant pursues when relying on the Convention and their compatibility with this instrument.', p. 8.

29 | Comp. Article 5 of the International Covenant on Civil and Political Rights; Art. 29 of the American Convention on Human Rights and article 54 of the Charter of Fundamental Rights of the European Union.

30 | Drooghenbroeck S. V., L'article 17 de la Convention européenne des droits de l'homme: incertain et inutile? In H. Dumont et al. Pas de liberté pour les ennemis de la liberté? Brussels, 2000, p. 141. 
abuse of the Convention by those who claim their right to free speech that is incompatible with the very foundations of the Convention. ${ }^{31}$ The first case before the Court, where Art. 17 was applied, was the Communist Party of Germany (KPD) v. Germany. By using Art. 17 of the Convention, the European Commission in 1957 rejected the claim of the applicant that their rights guaranteed under Art. 10 were violated and upheld the decision of the German Federal Constitutional Court to ban the party on the grounds that its program and activities aimed at the abolition of the democratic and liberal order of the state. ${ }^{32}$

The abuse clause applies to states, groups, and individuals, ${ }^{33}$ and the threshold for its application is very high. ${ }^{34}$ As clarified by the Court, its application is reserved only for the most serious forms of expressions that undermine the very foundations of the Convention. This was confirmed in the Court judgment Lilliendahl v. Iceland where the Court underlined that 'hate-speech' comprised two categories: one being its gravest form, which falls under Art. 17 of the Convention; another, which the Court considers 'less grave', but nevertheless possible for the Contracting States to sanction under the requirements set by Art. 10 of the Convention. According to the Court's case law, this category includes not only explicit calls for violence or other criminal acts but also insulting, holding up to ridicule or slandering of specific groups of the population subjected to prejudice..$^{35}$ Obviously, the facts of this case fall into the second category. The case concerned a private citizen who made online homophobic comments against the LGBTQ population. He referred to homosexuals as 'disgusting and deviant people indoctrinating children.' After being convicted and fined before the domestic court of the second instance, Mr. Lilliendahl claimed that his rights of free expression were violated by the authorities. The Court first found that, unlike in other hate speech cases, Art. 17 cannot be applied in this case because 'the applicant's comments were not immediately and clearly aimed at inciting to violence and hatred or destroying the rights and freedoms of others protected by the Convention.' ${ }^{36}$ It also reiterated that the abuse clause applies only exceptionally and in extreme cases, this particular case not being one of them. ${ }^{37}$

The abuse clause has an accessory function as a ground for dismissing claims of those whose speech was restricted by the authorities. In other words, Art. 17 has been

31 I It cannot be ruled out that a person or a group of persons will rely on the rights enshrined in the Convention or its Protocols in order to attempt to derive therefrom the right to conduct what amounts in practice to activities intended to destroy the rights or freedoms set forth in the Convention; any such destruction would put an end to democracy. It was precisely this concern which led the authors of the Convention to introduce Article 17, Ždanoka v. Latvia, §99. See also (see Collected Edition of the "Travaux Préparatoires": Official Report of the Consultative Assembly, 1949, pp. 1235-39). 32 | German Communist Party (KPD) v. Germany. The Commission quoted article 21 §2 of the Basic Law of the Federal Republic of Germany: 'Parties which, according to their aims and the behaviour of their members, seek to impair or abolish the free and democratic basic order or to jeopardise the existence of the Federal Republic of Germany, shall be anti-constitutional. The Federal Constitutional Court shall decide on the question of anti-constitutionality.' Upon the conclusion that the applicant's major political goal to establish 'a social-communist system by means of a proletarian revolution and the dictatorship of the proletariat' contravenes the fundamental values and guarantees enshrined in the Convention, the Commission applied article 17 and declared the application inadmissible.

33 | Supra note 10.

34 | Lilliendahl v. Iceland, §26.

35 | Ibid. $\$ 36$.

36 | Ibid. §26.

37 | Ibid. 
used in cases of 'speakers' when they appear as applicants, and not in cases of victims who apply to the Court for being targeted by either hate speech, negative stereotyping, and discrimination by the 'speakers.' A good example of this is a series of cases concerning the negative stereotyping of national minorities. In Budinova and Chaprazov v. Bulgaria, the Court concluded that statements of the well-known journalist and politician, all of which appear to have been deliberately couched in inflammatory terms, visibly sought to portray Roma in Bulgaria as exceptionally prone to crime and depravity...the statements were systematic and characterized by their extreme virulence (for instance expressions such as 'Gypsy terror over Bulgarian,' 'gigantic genocide of the Bulgarian nation')... the essence of his statements was that the Roma were immoral social parasites who abused their rights, lived off the back of the Bulgarian majority, subjected that majority to systematic violence and crime without hindrance, and aimed to take over the country... It is beyond doubt that this amounted to extreme negative stereotyping meant to vilify Roma in Bulgaria and to stir up prejudice and hatred towards them.'38 The same person was concerned in the case Behar and Gutman v. Bulgaria. That is why both judgments are strikingly similar in the explanation of reasons. The only distinction was that the targets of the impugned statements given in the book were not Roma but Jews:

"These statements were meant to vilify Jews and stir up prejudice and hatred towards them... they all rehearsed timeworn anti-Semitic and Holocaust-denial narratives. ...this becomes evident from their very wording, regardless of the broader context of the two books in which they featured." 39

In both cases, the Court found that domestic courts failed to protect community members' private lives that amounted to a violation of Articles 8 and 14 of the Convention. Although the issue of freedom of expression under Art. 10 was touched by the Court as an obiter dictum ${ }^{40}$, there was no reference to Art. 17 or a priori exclusion of that kind of negative stereotyping of a national minority from the application of the free speech clause. Some commentators found this problematic, arguing that failure to invoke the abuse clause in cases of evident hate speech towards the national minorities could undermine the victims' rights under the Convention..$^{41}$ This is, no doubt, another angle that fuels the ongoing debate about the controversies in applying the abuse clause.

38 | Budinova and Chaprazov v. Bulgaria, $\S 65$.

39 | Behar and Gutman v. Bulgaria, §104.

40 | Supra note 37, § 94.

41 | 'Is the Court (still) resisting the entitlement of community vilification victims when they seek, by litigating before it, empowerment directly-and through them, minorities-to the detriment of States? Is the Court prepared to go further than States upholding minority identity at the level of Language (the Symbolic)? Inconsistency, as evidenced by the asymmetries discussed above, tends to disadvantage disenfranchised people. Victims of minority othering possibly meet less judicial perceptiveness as case protagonists taking on a State partly due to an absence of corresponding perspectives on the inside of an institution. Are minority/ victimized perspectives adequately integrated via representation on the Court? Or is the compassion of the privileged (to be relied on as) sufficient? Ilieva M.S., Behar and Budinova v. Bulgaria: The Rights of Others in Cases of Othering-Anti-victim bias in ECHR hate speech law, 2021, available at https://strasbourgobservers. com/2021/04/15/behar-and-budinova-v-bulgaria-the-rights-of-others-in-cases-of-otheringanti-victim-bias-in-echr-hate-speech-law/, Accessed August 27, 2021. 
In addition to the uncertainties about the threshold for application of the abuse clause, there has also been a debate among the commentators about the inconsistencies in interpreting well-established historical facts in the context of genocide and other mass crimes. This debate highlighted the criteria adopted by the Court in genocide revisionist cases. As a standard, the Court established in Garaudy v. France ${ }^{42}$ that 'disputing the existence of clearly established historical events such as the Holocaust did not constitute historical research but was rather an effort to rehabilitate the Nazi regime and accuse Holocaust victims of falsifying history. ${ }^{13}$

While denial and revision of the Holocaust undoubtedly fall outside the scope of protected speech (case), according to the Court, the same does not apply to the Armenian genocide. In case of Perinçek v. Switzerland, the Court conducted a three-step test to determine whether the penalty that was imposed on the applicant for denial of the Armenian genocide (he said during his visit to Switzerland it is 'an international lie') in the course of criminal proceedings in Switzerland violated Art. 10 of Convention. The Court concluded that his rights under Art. 10 were violated because the necessity test indicates that the penalty imposed in criminal proceedings was not proportional to the legitimate aim of protecting the 'rights of others' (in this case Armenian community). In arriving at that conclusion, the Court took several elements into account, including the following: Mr. Perinçek's statements bore on a matter of public interest and did not amount to a call for hatred or intolerance; there was no international law obligation for Switzerland to criminalize such statements; the interference with Mr. Perinçek's right to freedom of expression had taken the serious form of a criminal conviction. ${ }^{44}$

What is interesting, however, is that in this case, the Court did not find it necessary to apply Art. 17 and to address the issue of whether denial of genocide in the Armenian case prima facie excludes protection under Art. 10 of the Convention. However, out of seven judges who dissented to the majority, four stressed that the Court failed by not applying the abuse clause. ${ }^{45}$ Concluding that the Court's approach to article 17 'in relation to genocide denial and other forms of hate speech has not been uniform ${ }^{\prime 6}$ these judges reminded about four different cases in which Art. 17 has been applied by the Court. The first is the direct application, with the effect of dismissing the application as inadmissible. For example, Glimmerveen and Hagenbeek v. the Netherlands, where the Commission found strongly racist views in contrast to the text and spirit of the Convention and dismissed the application.$^{47}$ In addition, there was an indirect application (combined approach). First, the Court subject the case to the standard three-step test under Art. 10 and then resorts to the abuse clause at the necessity stage to determine whether the application is manifestly ill-founded. ${ }^{48}$ In the third group of cases (for instance, Leroy v. France), Art. 17 might have

42 I The applicant was found guilty of disputing the existence of the Holocaust in his book 'The Founding Myths of Modern Israel.' He received suspended sentences of imprisonment, the longest being for six months and fines in excess of 25,900 Euros and compensation of more than 33,500 Euro for the civil parties.

43 | https://futurefreespeech.com/garaudy-v-france/, Accessed August 27, 2021.

44 | https://globalfreedomofexpression.columbia.edu/cases/ecthr-perincek-vswitzerland-no-2751008-2013/, Accessed 27 August 2021.

45 | Perinçek v. Switzerland, Additional dissenting opinion of judge Silvis, joined by judges Casadevall, Berro and Kūris, pp.125-127.

46 | Ibid. $\$ 2$.

47 | Ibid. §3.

48 | Ibid. §4. 
been applied but it was not. ${ }^{49}$ Finally, in some cases (fourth group), the Court first examines the merits and then addresses the issue of the potential application of Art. $17 .^{50}$

These uncertainties concerning the threshold and context for applying Art. 17 raise the question of appropriateness to apply this provision in fake news cases. This issue is addressed in the last section of this paper.

\section{Discussion and conclusion}

There are many intersections between Art. 17 of the Convention and the concept of disinformation (fake news). First, Art. 17 applies in cases where alleged expressions are contrary to the text and spirit of the Convention. The drafters of the Convention aimed to prevent the abuse of rights by those who propagated totalitarian ideologies, relativized mass crimes (particularly genocide), and systematically discriminated against members of national minorities. In such cases, the Court does not need to determine whether a particular restriction on the applicants' rights was in accordance with the standards under the Convention and its jurisprudence. Thus, it could be said that Art. 17 relieves the Court from the need to assess the legality and necessity of any individual restriction of the applicant's rights (free speech) by the national authorities by allowing the application to be dismissed as manifestly unfounded. This is understandable and justified because such abuses of rights could jeopardize the viability of the Convention and the unique human rights protection system it establishes.

At first glance, it could be said that the same logic applies to the concept of disinformation (fake news). In its radical sense, this concept is per se contrary to all values that the Convention promotes and protects. It is, first and foremost, the protection of human rights within the system of the rule of law of democratic states. These are the fundamental principles on which the regional organization of the Council of Europe, which recently marked its 70th anniversary, was created and further developed. Likewise, the abuse clause applies to states, groups, and individuals that correspond to the nature of the fake news that could be generated and disseminated by either of these subjects.

However, it should be noted that not all forms of fake news are the same, nor all of them reach the threshold for invoking Art. 17. Indeed, not all fake news is a threat to democracy. It goes only for those massive campaigns aimed at destabilizing the system, causing panic, creating confusion, and fueling social polarization. Likewise, in general, negligent and innocent fake news dissemination does not justify the application of criminal sanctions. Finally, fake news (disinformation) could raise the issue of the responsible subject, given that artificial intelligence often generates them.

Another relevant aspect is distinguishing fake news as untrue statements from other similar expressions, such as defamatory statements. The Court has emphasized that a careful distinction is to be made between factual statements on the one hand and value judgments on the other. While facts can be demonstrated, the truth of value judgments is not susceptible to proof. However, shifting the burden of proof about the truthfulness of the statement to the applicant could sometimes face him with an unreasonable, if not 
impossible, task. Since the measures taken by states in response to defamatory statements are not a priori excluded from exercising a three-step test under Art. 10, there are no convincing arguments why fake news (disinformation) should be treated differently.

There is also a concern that a priori exclusion of disinformation from careful juridical balancing under Art. 10 of the Convention could undermine the role of court, that is, to provide interpretation in terms of legitimate aim as well as the necessity and proportionality of the restriction in any given case (clarification role). Lifting this role by simply invoking Art. 17 of the Convention in fake news cases might question the simplistic approach to the issue and bring even more uncertainty in this field.

This is particularly important, having in mind not always consistent standards applied in cases that trigger the abuse clause. In other words, the threshold for using Art. 17 has not been apparent even in cases that are considered a prima facie denial of freedom of expression as the ones concerning hate speech, genocide denial, negative stereotyping of minorities, etc. The nuances of the clarification role of the Court in this regard were explained above in this paper while comparing different approaches to various types of hate speech (Norwood vis a vis Lilliendahl) and various types of mass crimes (Garaudy vis a vis Perincek). With these uncertainties in mind, it seems that bringing a relatively new and not quite clearly conceptualized phenomenon and subjecting it to this control mechanism may not be a good idea given the imperatives of legal certainty and substantive justice.

In conclusion, notwithstanding the anti-democratic and anti-liberal dimensions of some forms of fake news (particularly those integrated into large-scale disinformation campaigns) that, no doubt, runs contrary to the text and spirit of the Convention, many valid arguments justify the caution when it comes to the blanket lifting of free speech protection mechanism provided in Art. 10 of the Convention. Therefore, applying the abuse clause in the context of disinformation should be decided on a case-by-case basis, considering all the relevant arguments discussed in this paper. 


\section{Bibliography}

\section{| a. Books, articles}

Dalkir, K. and Katz, R. (2020). Navigating Fake News, Alternative Facts, and Misinformation in a Post-Truth World. IGI Global Disseminator of Knowledge.

Drooghenbroeck, S.V. (2000) 'L'article 17 de la Convention européenne des droits de l'homme: incertain et inutile?' In Dumont, H. et al. (eds.) Pas de liberté pour les ennemis de la liberté? Brussels.

Fathaigh, R. (2019) Brzeziński v. Poland: Fine over 'false' information during election campaign violated Article 10 [Online]. Available at: https://strasbourgobservers. com/2019/08/08/brzezinski-v-poland-fine-over-false-information-duringelection-campaign-violated-article-10/. (Accessed: 27 August 2021).

Ilieva, M.S. (2021) Behar and Budinova v. Bulgaria: The Rights of Others in Cases of Othering - Anti-victim bias in ECHR hate speech law [Online]. Available at: https:// strasbourgobservers.com/2021/04/15/behar-and-budinova-v-bulgaria-the-rightsof-others-in-cases-of-othering-anti-victim-bias-in-echr-hate-speech-law/ (Accessed: 3 December 2021).

Mueller, R. (2019) Report On the investigation into Russian interference in the 2016 presidential election (Vols. 1-2). Washington, DC: Academic Press.

Nielsen, G. (2020) Populism, Fake News, and the Flight From Democracy.

Peters, M.A., Rider, S., Hyvönen, M., Besley, T. (eds.) (2018) Post truth, fake news: Viral modernity and higher education. Singapore: Springer. doi:10.1007/978-981-10-8013-5.

Shattock, E. (2021) Should the ECtHR Invoke Article 17 for Disinformation Cases [Online]. Available at: https://www.ejiltalk.org/should-the-ecthr-invoke-article-17for-disinformation-cases/ (Accessed: 27 August 2021).

Tulkens, F. (2012) When to say is to do, Freedom of expression and hate speech in the case-law of the European Human Rights [Online]. Available at: https://www.ejtn.eu/ Documents/About\%20EJTN/Independent\%20Seminars/TULKENS_Francoise_ Presentation_When_to_Say_is_To_Do_Freedom_of_Expression_and_Hate_ Speech_in_the_Case_Law_of_the_ECtHR_October_2012.pdf, p. 4. (Accessed: 27 August 2021).

\section{| b. European Court of Human Rights Judgements}

| Handyside v. the United Kingdom, application no. 5493/72, 1976.

| Observer and Guardian v. the United Kingdom, application no. 13585/88, 1990.

| Prager and Oberschlick v. Austria, application no. 15974/90, 1995.

| Gündüzv. Turkey, application no. 35071/97, 2004.

| Garaudy v. France, application no. 64496/17, 2003. 
| Perinçek v. Switzerland, Grand Chamber, application no. 27510/08, 2015.

| Norwood v. the United Kingdom, application no. 23131/03, 2004.

| Feret v. Belgium, application no. 15615/07, 2009.

| Budinova and Chaprazov v. Bulgaria, application no. 12567/13, 2021.

| Mirolubovs and Others v. Latvia, application no. 798/05, 2009

| S.A.S. v. France, Grand Chamber, application no. 43835/11, 2014.

| Ždanoka v. Latvia, Grand Chamber, application no. 58278/00, 2006.

Communist Party of Germany (KPD) v. Germany, The European Commission of Human Rights, application no. 250/57, 1957.

| Lilliendahl v. Iceland, application no. 29297/18, 2020.

| Behar and Gutman v. Bulgaria, application no. 29335/13, 2021.

\section{| c. Other}

Guide on Article 10 of the European Convention on Human Rights, European Court of Human Rights, December 2020 [Online]. Available at: https://www.echr.coe.int/ documents/guide_art_10_eng.pdf.

Guide on Article 17 of the European Convention on Human Rights, European Court of Human Rights, August 2020 [Online]. Available at: https://www.echr.coe.int/ Documents/Guide_Art_17_ENG.pdf (Accessed 27 August 2021)

| Brandenburg v. Ohio, 395 U.S. 444 (1969).

Communication from the Commission to the European Parliament, the Council, the European economic and social committee and the Committee of the regions tackling online disinformation: a European approach. com/2018/236 final. https://eur-lex. europa.eu/legal-content/en/txt/?uri=celex\%3a52018dc0236.

Information Disorder: Toward an interdisciplinary framework for research and policy making, Council of Europe, 2017.

A multi-dimensional approach to disinformation, Report of the independent High level group on fake news and online disinformation, European Union, 2018.

| https://futurefreespeech.com/garaudy-v-france/.

https://globalfreedomofexpression.columbia.edu/cases/ecthr-perincek-vswitzerland-no-2751008-2013/.

| https://globalfreedomofexpression.columbia.edu/cases/gunduz-v-turkey/.

Convention for the Protection of Human Rights and Fundamental Freedoms, https:// www.echr.coe.int/documents/convention_eng.pdf.

| https://www.collinsdictionary.com/dictionary/english/fake-news. 